\title{
High genotypic diversity of the reef-building coral Porites lobata (Scleractinia: Poritidae) in Isla del Coco National Park, Costa Rica
}

\author{
Jennifer N. Boulay ${ }^{1}$, Jorge Cortés ${ }^{2}$, Jaime Nivia-Ruiz ${ }^{2} \&$ Iliana B. Baums $^{1}$
}

1. Department of Biology, The Pennsylvania State University, 208 Mueller Laboratory, University Park, Pennsylvania 16802, USA; jnb186@psu.edu

2. Centro de Investigación en Ciencias del Mar y Limnología (CIMAR), Universidad de Costa Rica, San Pedro, 115012060 San José, Costa Rica; jorge.cortes@ucr.ac.cr

Received 02-III-2012. C Corrected 25-IX-2012. Accepted 29-IX-2012.

\begin{abstract}
The isolated Isla del Coco experiences periodic, extreme disturbances which devastate coral reefs surrounding the island. Scleractinian corals build the physical structure of the reef therefore ecosystem recovery relies on coral species recovery. Coral recruits can be of sexual or asexual origin, and the relative success of the two recruit types influences the speed and spread of recovery processes. Here we focus on the massive coral, Porites lobata, because it is the main reef-builder around Isla del Coco to describe the relative contribution of asexual and sexual recruits to population maintenance. $P$. lobata samples were collected using a spatially explicit random sampling design in three plots at Isla del Coco: Punta Ulloa $(n=17)$, Bahía Weston $(n=20)$ and Punta María ( $\mathrm{n}=20)$ and samples were genotyped with 11 microsatellite markers. Additional sampling was conducted at three "coastal" sites near the Costa Rican mainland (Isla del Caño Biological Reserve): Caño1 (n=8), Caño2 $(n=10)$, Caño5 $(n=11)$ to compare the contributions of asexual and sexual recruits at Isla del Coco sites to coastal sites. Isla del Coco sites were characterized by small colony size $\left(>60 \%\right.$ of colonies $\left.<0.5 \mathrm{~m}^{2}\right)$ and high sexual reproduction. Sites were either mostly or entirely sexual,consisting of only unique genotypes $\left(\mathrm{N}_{\mathrm{G}} / \mathrm{N}=0.90-1.00\right.$; $\mathrm{G}_{\mathrm{O}} / \mathrm{G}_{\mathrm{E}}=0.83-1.00 ; \mathrm{D}=0.99-1.00$ ). Although there were no significant differences in genetic diversity (number of alleles per locus, number of private alleles) or colony size between Isla del Coco and the coastal sites, the coastal sites exhibited a greater range of genotypic diversity from moderately asexual $\left(\mathrm{N}_{\mathrm{G}} / \mathrm{N}=0.5 ; \mathrm{G}_{\mathrm{O}} / \mathrm{G}_{\mathrm{E}}=0.36\right.$; $\mathrm{D}=0.8)$ to purely sexual $\left(\mathrm{N}_{\mathrm{G}} / \mathrm{N}=1.0 ; \mathrm{G}_{\mathrm{O}} / \mathrm{G}_{\mathrm{E}}=1.0 ; \mathrm{D}=1.0\right)$. The mode of asexual reproduction in $P$. lobata is likely fragmentation of adult colonies rather than asexual larval production because ramets of $P$. lobata occurred close together and asexually produced larvae have not been reported in gonochoric broadcast spawners like P. lobata. Frequent sexual reproduction at Isla del Coco National Park might represent a resource for rapid recovery following extreme El Niño-Southern Oscillation (ENSO) disturbance events. In contrast, larger, asexuallyproduced fragments rather than smaller, sexually-produced larvae appear to have the advantage at some coastal sites. The high frequency of sexual reproduction at Isla del Coco indicates that not only are sexual partners available but also current conditions are favorable for the delivery of larvae and the rate of predation on small larval recruits must be moderate. Citation: Boulay, J.N., J. Cortés, J. Nivia-Ruiz \& I.B. Baums. 2012. High genotypic diversity of the reef-building coral Porites lobata (Scleractinia: Poritidae) in Isla del Coco National Park, Costa Rica. Rev. Biol. Trop. 60 (Suppl. 3): 279-292. Epub 2012 Dec 01.
\end{abstract}

Key words: Genotypic diversity, Porites lobata, Eastern Tropical Pacific, Scleractinian coral, fragmentation, Isla del Coco, Costa Rica.

Corals build the three-dimensional habitat of the reef ecosystem and thus act as foundation fauna (Bruno \& Bertness 2001). Scleractinian corals often have large geographic distributions and encounter steep environmental gradients across their ranges (Maina et al. 2011). For example, marginal environments at the edges of coral species' ranges are characterized by low species diversity and adverse environmental conditions (Veron 2000, Maina et al. 2011, Polidoro et al. 2012) yet, coral populations persist. In the Eastern Tropical Pacific (ETP), coral species diversity is lower than in the central, Indo-West Pacific region (Wells 1988, Glynn \& Ault 2000) and environmental conditions are suboptimal for reef growth because of 
the limited shallow water habitat, fluctuating seawater temperatures due to seasonal upwelling, high sedimentation rates and low aragonite saturation state (Cortés 1997, Glynn \& Ault 2000, Maina et al. 2011, Polidoro et al. 2012). Further, a 5000-8000km deep water barrier (Dana 1975, Grigg \& Hey 1992) now separates tropical eastern Pacific biotas from the IndoWest Pacific region. Darwin (1880) regarded this eastern Pacific barrier as "impassable", and Ekman (1953) concluded that it is the world's most potent marine barrier to larval dispersal. The combination of suboptimal environmental conditions and isolation has raised interest to understand how these reefs face adverse conditions. Because climate change is expected to increase environmental variability and decrease species diversity in more central locations (Hughes et al. 2003, Hoegh-Guldberg et al. 2007), investigating how coral populations persist in marginal habitats provides insights for the future of reefs.

Many coral species can maintain their populations via both sexual and asexual reproduction however, the relative importance of asexual and sexual reproduction can vary across coral species ranges (Stoddart 1984a, Baums et al. 2006) and be influenced by biotic and abiotic factors (Glynn et al. 1994, Legoff et al. 2004, Foster et al. 2007). Sexual reproduction in corals occurs via the release of either sperm alone (sperm casting) or the release of eggs and sperm (broadcast spawning) into the water column. Sexes can be separate (gonochorism) or together (hermaphroditism). Asexual reproductive modes are just as varied ranging from the release of asexual larvae, gemmae and polyps to fragmentation of adult colonies. Fragmentation is common in branching species such as Acropora but generally thought to be rare in massive species, with notable exceptions such as Montastraea annularis (Foster et al. 2007). The amount of sexual versus asexual recruitment in a population is directly proportional to the genotypic diversity (the number of distinct genets or clones) of a population. Thus, the genotypic diversity in a population gives an indication of the relative importance of asexual versus sexual reproduction to population maintenance.

The relative importance of sexual versus asexual reproduction to population maintenance has consequences for the resistance and resilience of populations. While asexual reproduction of potentially well adapted local genotypes allows for the persistence of populations in the absence of sexual partners and/or favorable conditions for larval recruits, genotypically depauperate populations are expected to be less resilient to abiotic and biotic disturbances (red queen hypothesis, Lively et al. 1990, Reusch et al. 2005). It is thus important to determine the levels of genotypic (and genetic) diversity of coral populations. Decreased levels of genotypic diversity in corals have been described in areas of intermediate and increased natural and anthropogenic disturbances (Hunter 1993, Coffroth \& Lasker 1998) and regions with lower connectivity among populations of corals (Baums et al. 2006). At the edge of a species' range, asexually produced coral colonies can dominate local populations of lower density compared to the center of the range (reviewed in Baums 2008), maybe due to the rarity of sexual partners. Concordantly, clonal reproduction was more frequent in marginal than central habitats for at least two species: Acropora palmata (Baums et al. 2006) and Pocillopora damicornis (Stoddart 1984a, 1984b, Miller \& Ayre 2004). In P. damicornis (Type I), an important reef builder in the Eastern Pacific, there is evidence of both sexual and asexual reproduction in the northern ETP but no information exists for the center of the range (Pinzón et al. 2012). Similarly, the importance of asexual versus sexual reproduction has not been determined for Porites lobata Dana, 1846, despite its prominent role as foundation fauna on Eastern Pacific sites such as the reefs of Isla del Coco.

Isla del Coco National Park $\left(5^{\circ} 32^{\prime} \mathrm{N}\right.$, $87^{\circ} 04^{\prime} \mathrm{W}$ ) is located approximately $500 \mathrm{~km}$ southwest of the Costa Rican mainland (Fig. 1A). The fringing reefs surrounding the island have the highest species richness of zooxanthellate corals among sites on the Pacific coast 

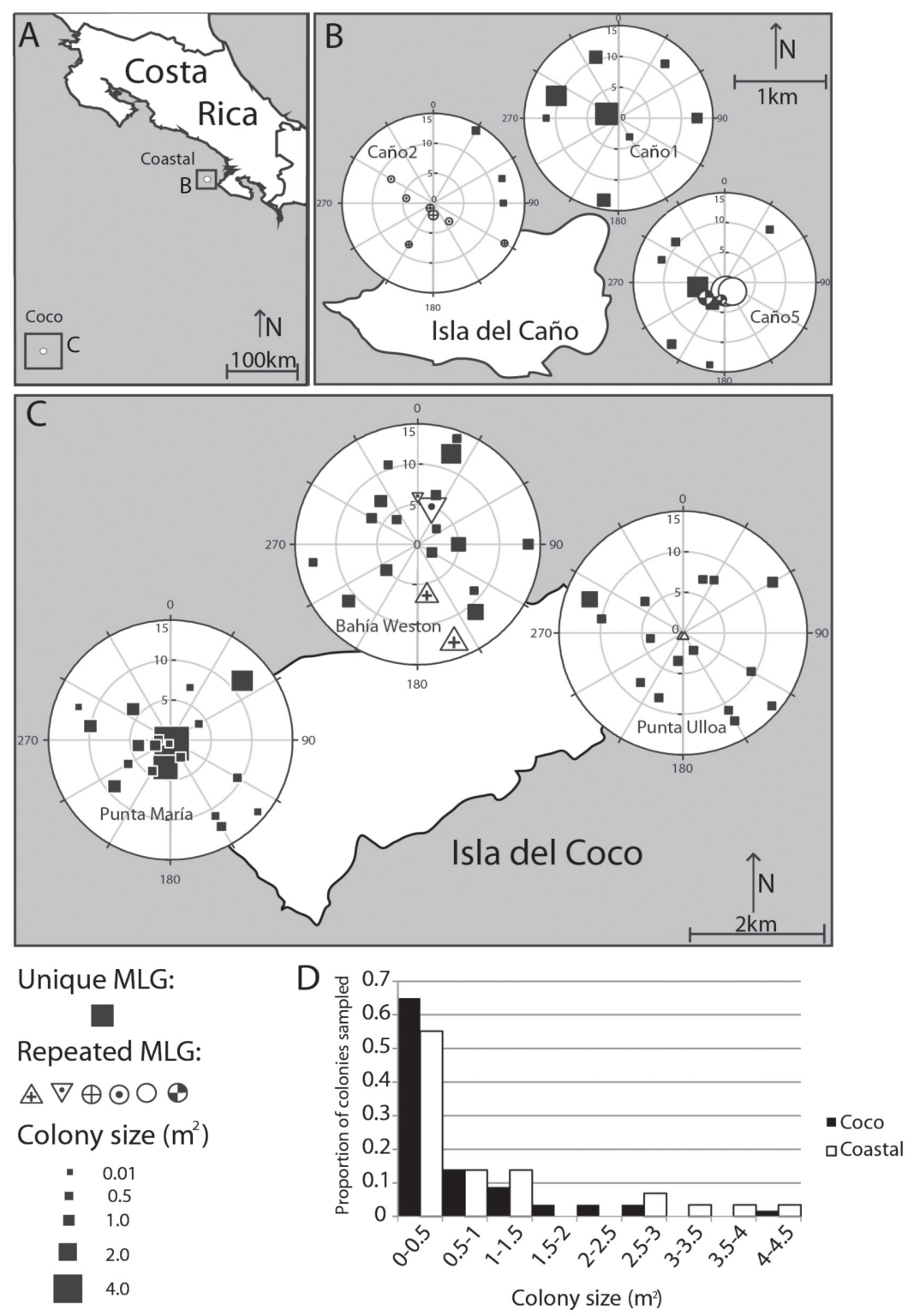

Fig. 1. Porites lobata was sampled randomly polar plots at oceanic and coastal sites in Costa Rica (A). Three plots each were sampled at the coastal Isla del Caño (B) and the oceanic Isla del Coco (C). Polar plots indicate the genotypic identity and size of $P$. lobata colonies sampled. Colonies with unique multi-locus genotypes (MLGs) are represented by a solid square. All other symbols indicate a repeated MLG. Ramets of the same genet are indicated by common symbols (except solid squares). Scale bar in (A) indicate distance in $\mathrm{km}$. In polar plots $\mathbf{( B ,} \mathbf{C})$, the radial axis shows distance $(\mathrm{m})$ in $5 \mathrm{~m}$ increments and the radial axis shows the angle in degrees in $30^{\circ}$ increments. Colony symbols were scaled by estimated colony area (range: 0.0096-4.32 $\mathrm{m}^{2}$ ). Size distribution of colonies sampled from Isla del Coco (black bars, $\mathrm{n}=57$ ) and coastal sites (white bars, $\mathrm{n}=33$ ) is shown in panel (D). 
of Costa Rica (Guzman \& Cortés 1992) but are dominated by few foundation species (Bakus 1975). Most of the reefs were constructed by Porites lobata but the agariciids and Pavona spp. are also common (Cortés et al. 2010). Unlike mainland Costa Rica which is affected more regularly by anthropogenic disturbances, the remote location of Isla del Coco and its National Park status renders it less impacted by humans (as reviewed in Cortés et al. 2010). However, natural disturbances in the form of El Niño-Southern Oscillation (ENSO) events are very common in the waters around Isla del Coco (Cortés 2008, Cortés et al. 2010). As a result of the 1982-1983 ENSO event live coral cover was depleted to 2.6 to $3.5 \%$ (Guzman $\&$ Cortés 1992). But some recovery has been observed. In 2000, live coral cover had reached $59 \%$ at one Isla del Coco site (Guzman \& Cortés 2007) despite punctuation by an additional severe bleaching event in 1996-1997. Hundreds of scientific papers have been published on the marine life at Isla del Coco mostly with a focus on taxonomy. In contrast, no known studies have been published on the dynamics of populations, behavior, or genetic makeup of any marine species on the island (Cortés 2008). The periodic natural disturbances and marginal location of Isla del Coco combined with the dominance of few coral foundation species increase the importance of examining the relative importance of sexual versus asexual reproduction to population maintenance of foundation corals at Isla del Coco. Thus, we investigated the genetic and genotypic diversity of a dominant reef builder at Isla del Coco, $P$. lobata, at Isla del Coco National Park and contrast it with the diversity found at more coastal sites along the Costa Rican mainland.

\section{MATERIALS AND METHODS}

Study species: Porites lobata Dana, 1846 (Scleractinia: Poritidae) is a massive, slowgrowing, gonochoric, broadcast-spawning species, that also reproduces asexually by partial mortality or fish-induced fragmentation (Cortés 1997). It has a Pacific-wide distribution and dominates reefs in lower latitudes of the ETP and on oceanic islands such as Isla del Coco (Glynn et al. 1994, Guzman \& Cortés 2007). In Costa Rica, it is the dominant reef-building coral (Cortés \& Guzman 1998) constituting over $90 \%$ of the best developed reefs in the country, including Isla del Coco (Guzman \& Cortés 1992), Isla del Caño (Guzman \& Cortés 1989), and Punta Islotes in Golfo Dulce (Cortés 1992).

Study sites: $P$. lobata colonies were sampled in April 2010 at Punta Ulloa, Bahía Weston and Punta María in Isla del Coco National Park, Costa Rica ("oceanic sites"). Colonies at Bahía Weston and Punta Ulloa were located $4-7 \mathrm{~m}$ deep. Punta María is a deeper site with P. lobata colonies found 10-12m deep. For comparison, three inshore Costa Rican sites ("coastal sites") were also sampled in Isla del Caño Biological Reserve. These sites were designated Caño1, Caño2 and Caño5.

Sampling method: The sampling design followed Baums et al. (2006). Coral fragments were collected under randomly generated coordinates in $15 \mathrm{~m}$ radius circular plots (Fig. 1B-C). One plot was sampled at each site (see Study Sites) for a total of three plots at Isla del Coco and three coastal plots. Coordinates had a precision of $5^{\circ}$ of arc and of $0.5 \mathrm{~m}$ along strike and were generated using the random number generation function in Microsoft Excel. Using a compass and a measuring tape secured to the center point of the circle, coordinates were located by a team of SCUBA divers. The center of the plot was diver selected to maximize colony density and therefore sampling feasibility. The colony (defined as a mounding coral skeleton covered by continuous tissue growth) underneath each coordinate was sampled using a hammer and chisel to break off a small fragment of coral tissue (maximum size $1 \mathrm{~cm} \mathrm{x}$ $1 \mathrm{~cm})$. An underwater photograph was taken of each colony sampled for future reference, and each colony's maximum length, width, and height was measured to the nearest $10 \mathrm{~cm}$. The same colony was never sampled twice and 
sampling of a plot ceased when 20 colonies were collected to standardize sampling effort. However, previously unknown cryptic species diversity within morphologically similar Porites colonies was revealed by genotyping post-sampling (Boulay et al. in prep) and reduced the sample sizes of $P$. lobata in the Coastal plots and Punta Ulloa (see genotyping results for further discussion). Fragments were placed in individual zip-lock bags underwater and then transferred to vials containing 95\% ethanol. Fragments were stored in a $-20^{\circ} \mathrm{C}$ freezer until DNA extraction and genetic analysis could be performed.

Genotyping: Genomic DNA was extracted following the manufacturer's instructions using the DNeasy 96 Blood and Tissue Kit (Qiagen, CA). Multi-locus genotypes (MLGs) were established for each colony using a total of eleven microsatellite loci (Appendix Table 1) that have been used in previous studies (Polato et al. 2010, Baums et al. 2012). Polymerase chain reactions were run in four multiplex reactions consisting of two to three primer pairs each and one singleplex reaction. Primer sets were labeled with NED, VIC, PET, or 6FAM (Applied Biosystems, CA). PCR conditions consisted of an initial denaturation step of $95^{\circ} \mathrm{C}$ for $5 \mathrm{~min}$, followed by 35 cycles $\left(95^{\circ} \mathrm{C}\right.$ for $20 \mathrm{~s}$; melting temperature of $52^{\circ} \mathrm{C}-56^{\circ} \mathrm{C}$ depending on the microsatellite for $20 \mathrm{~s}$; and $72^{\circ} \mathrm{C}$ for $30 \mathrm{~s})$. A final extension of $30 \mathrm{~min}$ at $72^{\circ} \mathrm{C}$ was used to ensure the addition of a terminal adenine to all products (Brownstein et al. 1996). PCR products were visualized using an $\mathrm{ABI}$ 3730 automated sequencer and internal size standards (Genescan LIZ-500; Applied Biosystems, CA) were used to determine the size of the products. Alleles were scored based on amplicon size using Genemapper 4.0 (Applied Biosystems, CA).

Analysis of multi-locus genotype data: Multi-locus genotypes (MLGs) were determined in GenAlEx vers 6.4 by requiring complete matches at all loci (Peakall \& Smouse 2006) ignoring missing alleles. Potential genotyping errors were detected with GenClone 2.0 (Arnaud-Haond \& Belkhir 2007) and spurious allele calls were corrected. Genotypic and genetic diversity indices were calculated. Genotypic diversity refers to the number of unique multi-locus genotypes and varies on the level of whole organisms. In contrast, genetic diversity measures allele diversity of individual loci in a population. Genotypic diversity indices such as genotypic richness $\left(\mathrm{N}_{\mathrm{G}} / \mathrm{N}\right)$, genotypic diversity $\left(\mathrm{G}_{\mathrm{O}} / \mathrm{G}_{\mathrm{E}}\right)$ and genotypic evenness $\left(\mathrm{G}_{\mathrm{O}} / \mathrm{N}_{\mathrm{G}}\right)$ were calculated (Table 1) for each site. Genotypic richness is directly proportional to the frequency of sexual recruitment and is

TABLE 1

Genotypic diversity in Porites lobata within and between coastal and oceanic sites (one plot per site) in the Eastern Tropical Pacific

\begin{tabular}{lccccccccccc} 
& Site & $\mathrm{N}^{1}$ & $\mathrm{~N}_{\mathrm{G}}{ }^{2}$ & $\mathrm{MAX}^{3}$ & $\mathrm{~N}_{\mathrm{G}} / \mathrm{N}^{4}$ & $\mathrm{G}_{\mathrm{O}}{ }^{5}$ & $\mathrm{G}_{\mathrm{O}} / \mathrm{G}_{\mathrm{E}}{ }^{6}$ & $\mathrm{G}_{\mathrm{O}} / \mathrm{N}_{\mathrm{G}}{ }^{7}$ & $\mathrm{D}^{8}$ & $\mathrm{H}^{9}$ & $\mathrm{P}_{\mathrm{ID}}{ }^{10}$ \\
Isla del Coco & Punta Ulloa & 17 & 16 & 2 & 0.94 & 15.21 & 0.89 & 0.95 & 0.99 & 1.20 & $2.6 \times 10^{-08}$ \\
National Park & Bahía Weston & 20 & 18 & 2 & 0.90 & 16.67 & 0.83 & 0.93 & 0.99 & 1.24 & $8.6 \times 10^{-09}$ \\
& Punta María & 20 & 20 & 1 & 1.00 & 20.00 & 1.00 & 1.00 & 1.00 & 1.30 & $8.9 \times 10^{-09}$ \\
Total & 3 sites & 57 & 54 & 2 & 0.95 & & & & & & $6.0 \times 10^{-09}$ \\
Caño Island & Caño1 & 8 & 8 & 1 & 1.00 & 8.00 & 1.00 & 1.00 & 1.00 & 0.90 & $5.6 \times 10^{-00}$ \\
National Park & Caño2 & 10 & 5 & 4 & 0.50 & 3.57 & 0.36 & 0.71 & 0.80 & 0.62 & $4.2 \times 10^{-08}$ \\
& Caño5 & 11 & 9 & 2 & 0.82 & 8.07 & 0.73 & 0.90 & 0.96 & 0.93 & $2.8 \times 10^{-09}$ \\
Total & 3 sites & 29 & 22 & 4 & 0.76 & & & & & & $3.6 \times 10^{-09}$ \\
\hline
\end{tabular}

1. $\mathrm{N}=$ number of samples. $2 . \mathrm{N}_{\mathrm{G}}$ = number of genotypes. 3. MAX $=$ maximum ramets per genet. $4 . \mathrm{N}_{\mathrm{G}} / \mathrm{N}=$ clonal richness. 5. $\mathrm{G}_{\mathrm{O}}=$ observed genotypic diversity. 6. $\mathrm{G}_{\mathrm{O}} / \mathrm{G}_{\mathrm{E}}=$ genotypic diversity (Stoddart \& Taylor 1988). 7. $\mathrm{G}_{\mathrm{O}} / \mathrm{N}_{\mathrm{G}}=$ evenness (Stoddart \& Taylor 1988). 8. D = Simpson's diversity . 9. H = Shannon-Weiner diversity. 10. PID = Probability of identity. 
calculated by dividing the number of unique genotypes (genets; $\mathrm{N}_{\mathrm{G}}$ ) by the total number of samples (N). Genotypic diversity is calculated by dividing the observed $\left(\mathrm{G}_{\mathrm{O}}\right)$ over the expected $\left(\mathrm{G}_{\mathrm{E}}\right)$ genotypic diversity (Stoddart \& Taylor 1988). Microsatellites are highly polymorphic markers and thus each sample is expected to be genetically distinct in a sexually reproducing population. The probability of identity $\left(\mathrm{P}_{\mathrm{ID}}\right)$ in this system was expected to be low based on previous studies of $P$. lobata using this marker system. The greatest $\mathrm{P}_{\text {ID }}$ for any site in this study is $5.6 \times 10^{-8}$ therefore, the expected number of genotypes $\left(\mathrm{G}_{\mathrm{E}}\right)$ is equal to the number of colonies genotyped and does not have to be estimated (see Baums et al. 2006). Observed genotypic diversity, $\mathrm{G}_{\mathrm{O}}$, is calculated by the inverse of the sum of the square of $n_{i}$ (the number of individuals of genotype $i$ found in the total number of samples) divided by $\mathrm{N}$. If the colonies in the population are all sexually produced $\mathrm{G}_{\mathrm{O}}$ will be equal to $\mathrm{N}$. Therefore, genotypic diversity is maximized in a solely sexual population $\left(\mathrm{G}_{\mathrm{O}} / \mathrm{G}_{\mathrm{E}}=1\right)$ and approaches zero when all colonies are asexually produced. Lastly, a measure of genotypic evenness is calculated by dividing observed genotypic diversity by the number of unique genotypes $\left(\mathrm{G}_{\mathrm{O}} / \mathrm{N}_{\mathrm{G}}\right)$. In contrast to richness, evenness is more influenced by genet longevity than recruitment. Evenness will approach zero when the population is dominated by one genotype but will approach 1 when each genotype has an equal number of member colonies (ramets). Simpson's corrected diversity (D), and Shannon-Wiener corrected diversity (H), were also calculated for each site using GenoDive (Meirmans \& Van Tienderen 2004). Simpson's diversity is independent of sample size. However, the Shannon-Wiener index is highly biased by sample size and rarely used for genetic studies except where sample sizes are similar. The genetic diversity was estimated by: the number of alleles $\left(\mathrm{N}_{\mathrm{A}}\right)$, number of effective alleles $\left(A_{E}\right)$, and number of private alleles $\left(\mathrm{A}_{\mathrm{P}}\right)$ and average observed $\left(\mathrm{H}_{\mathrm{O}}\right)$ and expected $\left(\mathrm{H}_{\mathrm{E}}\right)$ heterozygosity (Table 2$)$. Each richness, diversity, and evenness index averaged over sites within regions was compared between regions (Isla del Coco versus Coastal) using t-tests after checking for equal variance (Levene test, $\mathrm{p}>0.05$ ) and normality (ShapiroWilk, $\mathrm{p}>0.05$ ). Simpson's diversity (D) violated the assumptions of normality and equal variance and thus a non-parametric comparison was performed (Mann Whitney U test).

Characterization of sites: The relation between richness and evenness $\left(\mathrm{G}_{\mathrm{O}} / \mathrm{G}_{\mathrm{E}}\right.$ vs $\mathrm{G}_{\mathrm{O}} /$ $\mathrm{N}_{\mathrm{G}}$ ) characterizes the relative contribution of sexual recruitment and longevity of colonies to population structure and was used to classify each site into three groups (Baums et al. 2006). The first group was characterized by sexual

TABLE 2

Genetic diversity in Porites lobata within and between coastal and oceanic sites (one plot per site) in the Eastern Tropical Pacific

\begin{tabular}{|c|c|c|c|c|c|c|c|c|}
\hline & Site & $\mathrm{A}_{\mathrm{N}}{ }^{1}$ & $\mathrm{~A}_{\mathrm{E}}^{2}$ & $\mathrm{~A}_{\mathrm{p}}{ }^{3}$ & $\mathrm{H}_{\mathrm{O}}^{4}$ & $\mathrm{H}_{\mathrm{E}}^{5}$ & Latitude $(\mathrm{N})$ & Longitude (W) \\
\hline Isla del Coco & Punta Ulloa & 4.36 & 2.71 & 0.18 & 0.55 & 0.60 & $05^{\circ} 33^{\prime}$ & $87^{\circ} 02^{\prime}$ \\
\hline \multirow{2}{*}{$\begin{array}{l}\text { National Park } \\
\text { (oceanic) }\end{array}$} & Bahía Weston & 4.64 & 2.90 & 0.27 & 0.54 & 0.62 & $05^{\circ} 33^{\prime} 08.2^{\prime \prime}$ & $87^{\circ} 03^{\prime} 03.2^{\prime \prime}$ \\
\hline & Punta María & 5.00 & 2.87 & 0.73 & 0.50 & 0.61 & $05^{\circ} 32^{\prime} 05.4^{\prime \prime}$ & $87^{\circ} 05^{\prime} 15^{\prime \prime}$ \\
\hline Total & 3 sites & & & & & & & \\
\hline \multirow{3}{*}{$\begin{array}{l}\text { Caño Island } \\
\text { National Park } \\
\text { (coastal) }\end{array}$} & Caño1 & 3.82 & 2.64 & 0.09 & 0.52 & 0.58 & $08^{\circ} 42^{\prime} 39^{\prime \prime}$ & $83^{\circ} 51^{\prime} 54^{\prime \prime}$ \\
\hline & Caño2 & 3.64 & 2.82 & 0.09 & 0.45 & 0.57 & $08^{\circ} 42^{\prime} 43^{\prime \prime}$ & $83^{\circ} 52^{\prime} 56^{\prime \prime}$ \\
\hline & Caño5 & 4.82 & 3.17 & 0.36 & 0.56 & 0.62 & $08^{\circ} 42^{\prime} 32^{\prime \prime}$ & $83^{\circ} 52^{\prime} 01^{\prime \prime}$ \\
\hline Total & 3 sites & & & & & & & \\
\hline
\end{tabular}

1. $A_{N}=$ number of alleles per locus. 2. $A_{E}=$ effective number of alleles per locus. 3. $A_{P}=$ number of private alleles per locus. 4. $\mathrm{H}_{\mathrm{O}}=$ observed heterozygosity. 5. $\mathrm{H}_{\mathrm{E}}=$ expected heterozygosity. 
reproduction apparent by the maximization of both indices. The second group was considered to reproduce mainly sexually and the third was dominated by fragmentation as richness and evenness were low. K-means clustering of sites was performed using the squared Euclidian distance of only the uncorrelated (Pearson correlation, corrected $\mathrm{p}>0.001)$ diversity estimates: $\mathrm{G}_{\mathrm{O}} / \mathrm{G}_{\mathrm{E}}, \mathrm{D}$, and $\mathrm{N}_{\mathrm{G}} / \mathrm{N}$. Selection of the most likely cluster followed Calinski \& Harabasz' pseudo-F, Akaike Information Criterion, and Bayesian Information Criterion as calculated in GenoDive (Meirmans \& Van Tienderen 2004).

\section{RESULTS}

Size distribution of colonies: Colony size $\left(\mathrm{m}^{2}\right)$ was estimated by multiplying length and width measurements and resulting sizes were divided into nine uniform $0.5 \mathrm{~m}^{2}$ size classes ranging from $0-4.5 \mathrm{~m}^{2}$. P. lobata colony size was skewed towards small colonies with few large colonies over $4 \mathrm{~m}^{2}$ observed (Fig. 1D). A significantly larger proportion of colonies was found in the smallest size class $\left(0-0.5 \mathrm{~m}^{2}\right)$ compared to other size classes (one way ANOVA, post-hoc Tukey test, $\mathrm{p}<0.001)$. The proportion of small colonies at Isla del Coco was $66 \%(\mathrm{SD}=25 \%)$. There was no significant difference (t-test; $\mathrm{p}>0.05$ ) in the size of colonies between regions (Mean-Size ${ }_{\mathrm{COCO}}=0.63 \pm$ $0.85 \mathrm{~m}^{2}$; Mean-Size COASTAL $=0.94 \pm 1.20 \mathrm{~m}^{2}$ ) or between unique colonies and those belonging to a repeated MLG (Mean-Size $\mathrm{UNIQUE}=0.64 \pm$ $0.85 \mathrm{~m}^{2}$; Mean-Size REPEAT $=1.11 \pm 1.38 \mathrm{~m}^{2}$ ).

Genotyping: The total number of samples collected at both sites was comparable $\left(\mathrm{n}_{\mathrm{COCO}}=58 ; \mathrm{n}_{\text {COASTAL }}=60\right)$. However, genotyping revealed that many of these samples were actually Porites evermanni (Boulay et al. in prep) particularly at Isla del Caño where $P$. evermanni samples composed over half of the collection $(n=31)$. Because this study was designed to describe population genetic structure of Porites on Isla del Coco, and P. lobata is the dominant Porites on this island, the following results focus on P. lobata only. Genotype assignments were given to all $P$. lobata samples collected from Isla del Coco $(\mathrm{n}=57)$ and Isla del Caño $(n=29)$. Amplification resulted in an overall average failure of $6 \%(\mathrm{SD}=7 \%)$ at Isla del Coco and 3\% (4\%) at the coastal/mainland sites, and a per locus failure rate of $<16 \%$ for each locus in the included samples. No individual was missing data at more than two loci. At total of 48 of the 86 individuals had complete multi-locus genotypes at all loci. The probability of identity $\left(\mathrm{P}_{\mathrm{ID}}\right)$ for 11 microsatellite loci applied here ranged from $8.9 \times 10^{-9}$ at Punta María to $5.6 \times 10^{-8}$ at Caño1 (Table 2). Thus, the power to distinguish between similar but nonidentical multi-locus genotypes was high. Further, the $\mathrm{P}_{\mathrm{ID}}$ when only 9 loci were considered was also sufficiently small to justify inclusion of individuals with missing data $\left(\mathrm{P}_{\text {IDCOCO }}=6.7\right.$ $\left.\times 10^{-7} ; \mathrm{P}_{\text {IDCOASTAL }}=4.3 \times 10^{-7}\right)$.

The contribution of fragmentation to population structure: At Isla del Coco, the analysis of 57 samples resulted in 54 unique multi-locus genotypes (genets); indicating that sexual reproduction is the main reproductive strategy on this island. The three repeated MLGs consisted of only two ramets per genet each and ramets were always confined to a single sampling plot. The range of separation between the clonemates was from 1 to $7 \mathrm{~m}$. Every colony $(n=20)$ at the deepest of the three sites, Punta María, represented a unique MLG (Fig. 1C). At Punta Ulloa ( $\mathrm{n}=17)$, two ramets were found separated by a distance of less than $0.5 \mathrm{~m}$ (Fig. 1C). At Bahía Weston ( $\mathrm{n}=20)$, fragmentation was observed in the largest two colonies in the plot (Fig. 1C); one pair of ramets was separated by $6.69 \mathrm{~m}$ and another pair separated by a distance of $2.14 \mathrm{~m}$ (Fig. 1C).

At the coastal sites there were 22 unique genotypes out of the 29 Porites lobata samples. In repeated MLGs, the number of ramets per genet ranged from two at Caño5 $(n=11)$ to four at Caño2 ( $\mathrm{n}=10)$ (Fig. 1B). At Caño1 $(n=8)$ all colonies were unique (Fig. 1B). At Caño5 (Fig. 1B) ramets were separated by a distance of less than $3 \mathrm{~m}$ but at Caño2, ramets were distributed over distances up to 
15.7m; Fig. 1B). At Caño5 fragmentation was observed (Fig. 1B) due to partial mortality or fission of a large colony; but, at the shallower Caño2, some of the smallest colonies were asexually produced (Fig. 1B) and distributed over greater distances suggesting propagation of small rolling fragments.

In summary, genotypic diversity at Isla del Coco sites was high with indices ranging from 0.83 to 1.0 (Table 1). Variability among sites was low with one standard deviation ranging from 1 to $8 \%$. At the coastal sites, genotypic diversity indices were not on average different to those observed at Isla del Coco (between 0.36 and 1.0) but variance was higher $(p=0.006$, Simpson's D). Only Shannon-Weiner diversity was significantly different between Isla del Coco and the coastal sites likely due to its strong dependence on sample size (Fig. 2A).

Genetic diversity: Colonies at Isla del Coco carried $4.67 \pm 0.32$ alleles per locus $(2.83 \pm 0.10$ effective alleles) versus $4.09 \pm 0.64$ alleles per locus at the coastal sites (Fig. 2B). Mean observed heterozygosity across sites was $0.53 \pm 0.03$ (Fig. 2B). Punta María exhibited a relatively high number of private alleles $(0.73)$ per locus while Punta Ulloa, Bahía Weston and
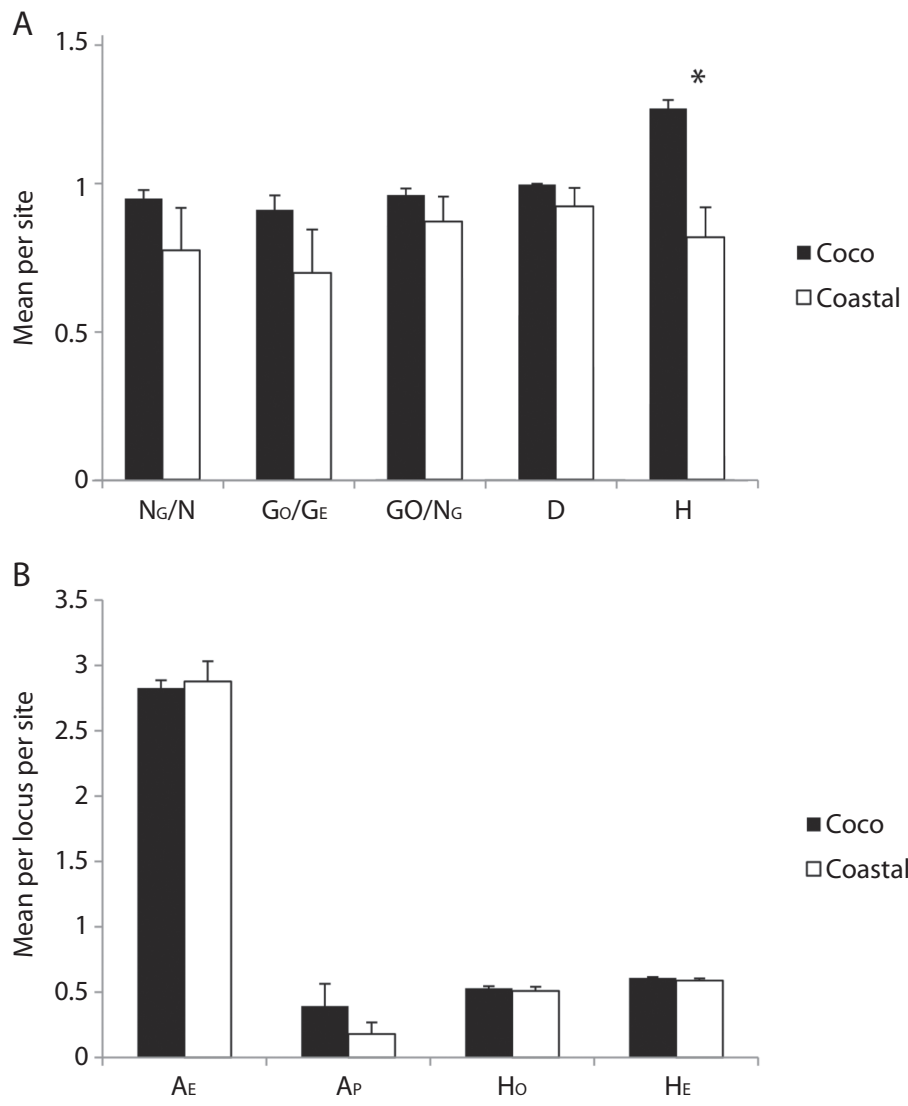

Fig. 2. Mean (+1 standard error) of genotypic (A) and genetic (B) diversity indices averaged over all loci (where appropriate) and sites per region (Isla del Coco=black bars; Coastal sites=white bars) in Porites lobata. Genotypic indices (A): clonal richness $\left(\mathrm{N}_{\mathrm{G}} / \mathrm{N}\right)$, genotypic diversity $\left(\mathrm{G}_{\mathrm{O}} / \mathrm{G}_{\mathrm{E}}\right)$ (Stoddart \& Taylor 1988), evenness $\left(\mathrm{G}_{\mathrm{O}} / \mathrm{N}_{\mathrm{G}}\right)$ (Stoddart \& Taylor 1988), Simpson's diversity (D), Shannon-Weiner diversity $(\mathrm{H})$. Genetic indices (B): effective number of alleles per locus $\left(\mathrm{A}_{\mathrm{E}}\right)$, number of private alleles per locus $\left(\mathrm{A}_{\mathrm{P}}\right)$, observed heterozygosity $\left(\mathrm{H}_{\mathrm{O}}\right)$, expected heterozygosity $\left(\mathrm{H}_{\mathrm{E}}\right)$. Each statistic was tested for significant differences between Isla del Coco and the coastal region using t-test. ${ }^{*} \mathrm{p}<0.05$. 
the coastal sites had fewer than 0.36 private alleles per locus (Table 2). No differences were observed between the coastal island and oceanic Isla del Coco for any genetic diversity index (Fig. 2B).

Characterization of sites: K-means clustering based on the relationship between genotypic richness and evenness of sites resulted in three clusters (Fig. 3). Punta María and Caño1 clustered together as entirely sexual. Bahía Weston, Punta Ulloa, and Caño5 formed a second cluster and are mostly sexual. Caño2 is distinct from the remaining sites and was dominated by fragmentation (Fig. 3).

\section{DISCUSSION}

The relative contributions of asexual and sexual recruitment to local population structure of coral species influences how coral populations recover from large scale disturbance events and what consequences such events have on the genetic diversity of the species. Recovery from sexual recruits would increase the genetic and genotypic diversity whereas

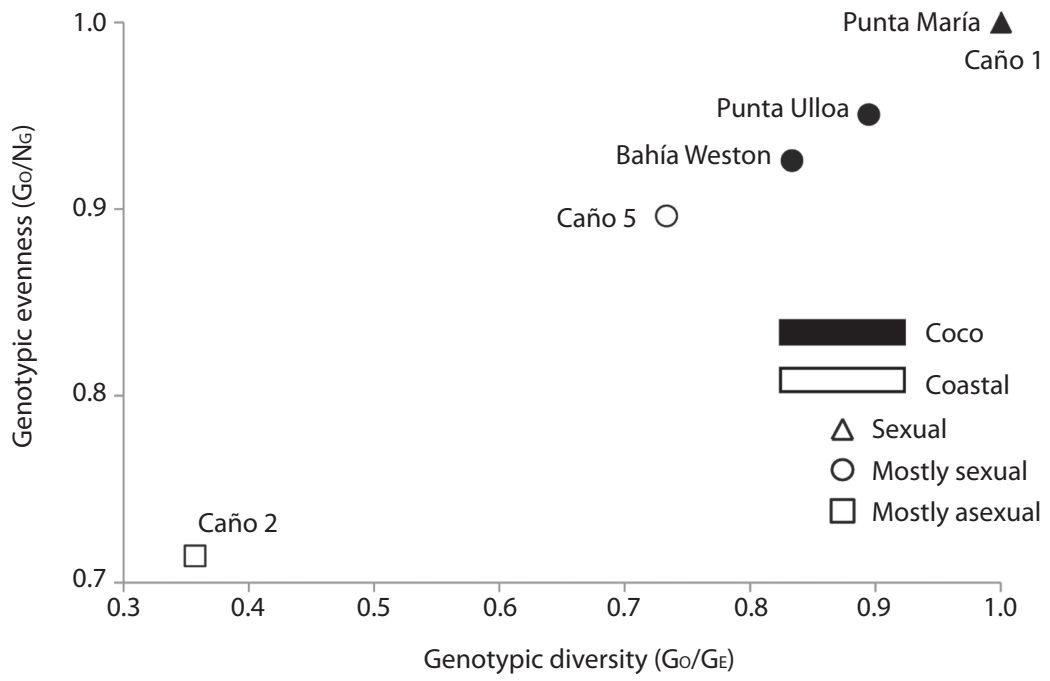

Fig. 3. Clonal structure of Porites lobata colonies sampled at six sites in Costa Rica. The relation of genotypic evenness $\mathrm{G}_{\mathrm{O}} /$ $\mathrm{N}_{\mathrm{G}}$ to diversity $\mathrm{G}_{\mathrm{O}} / \mathrm{G}_{\mathrm{E}}$ combined with $\mathrm{K}$-means clustering procedure resulted in three groups of sites (indicated on graph by distinct symbol shapes). The two purely sexual sites, Punta María and Caño1, have overlapping symbols. Fill of symbols indicate the region to which the sampling sites belong (Isla del Coco=black; coastal sites=white). recovery from regrowth can only preserve existing genotypic diversity. Without genetic markers, it is difficult to distinguish between these two recovery models because small colony sizes are indicative of sexual recruitment of coral larvae as well as regrowth from remnant tissue of colonies that have suffered partial mortality (Miller et al. 2007). Here, we demonstrate a high contribution of sexual reproduction to population maintenance for the framework building coral, Porites lobata, on recovering reefs at coastal and oceanic sites. This result gives a genetic basis to argue that recovery from recent (1982-83 and 1996-97) severe disturbance events proceeded chiefly via sexual recruitment and is concurrent with data demonstrating high sexual recruitment of Pocillopora in the ETP (Flot et al. 2010, Combosch \& Vollmer 2011, Pinzón \& Lajeunesse 2011). This is encouraging because it implies adult coral population densities high enough to generate sexual larvae as well as favorable conditions for survival of young recruits leading to the establishment of genetically diverse and thus more resilient populations. 
Sexual recruits can be of local or distant origin. An analysis of population structure in $P$. lobata across the entire Pacific basin suggests a biophysical barrier restricting gene flow between central and eastern Pacific populations. However, no further substructure was shown among $P$. lobata sampled from ten ETP locations, including Isla del Coco, Isla del Caño, mainland Costa Rica and the Galapagos archipelago (Baums et al. 2012). It is thus likely that the local population at Isla del Coco is recruiting from other ETP sites such as the Galapagos Islands, mainland Costa Rica, or Panama, in addition to local larval production (Baums et al. 2012). Similarly high connectivity among populations was evident in two Pocillopora species within the ETP (Pinzón \& Lajeunesse 2011). ENSO events in the ETP can cause large-scale disturbances with wide-spread adult coral mortality but apparently local populations at coastal and remote oceanic sites receive larval subsidies that aid in recovery.

The genetic evidence presented here suggests that fragmentation and reattachment of fragments occurs at low frequency in P. lobata at Isla del Coco even in large colonies $\left(>2.5 \mathrm{~m}^{2}\right)$. Evidence of limited asexual reproduction at Isla del Coco is congruent with findings for $P$. lobata populations across the Hawaiian Archipelago (Polato et al. 2010) as well as $P$. damicornis populations at scales over $5 \mathrm{~m}$ along the Panamanian coast (Combosch \& Vollmer 2011), Clipperton Atoll (Flot et al. 2010) and across the ETP (Pinzón \& Lajeunesse 2011). In the few instances of clonal reproduction at Bahía Weston and Caño5, large colonies likely survived the recent ENSO events but underwent partial mortality and fragmented as suggested by Guzman and Cortés (2007) and supported here by genetic evidence.

While average diversity did not differ between the oceanic and coastal islands, variability in the prevalence of clonal genotypes among sites was increased at the more environmentally variable coastal sites compared to the oceanic sites. Similar high variance in the contribution of asexual reproduction to population maintenance was observed at coastal sites in Mexico for Pocillopora Type I (Pinzón et al. 2012). In massive corals, the only data for asexual reproduction comes from analyses of clonal structure in Montastrea annularis in the Caribbean. There, we also see variation in the contribution of asexual reproduction to population maintenance with some sites dominated by clones. However this system differs from Porites because fragmentation is driven mainly by abiotic patterns of hurricane frequencies (Foster et al. in review).

This is in contrast to the mainly biotic factors controlling fragmentation observed in the ETP. The curious mode of triggerfishinduced fragmentation warrants future studies aimed at comparing the influence of mussels and triggerfish on coral fragmentation between regions in the ETP. Variation in the contribution of asexual and sexual recruitment to population maintenance may be related to variation in the distributions of the triggerfish species and the boring mussels on which they specialize. One ETP endemic triggerfish species, which specializes on endolithic bivales at Isla del Caño (Guzman \& Cortés 1989), was found in biogeographic surveys at Isla del Caño to be at moderate abundance (8.4 individuals/hectare; Guzman 1988) particularly at the base of the reef but, has not been recorded at the major offshore islands such as Isla del Coco (Berry \& Baldwin 1966). To understand the mechanisms controlling diversity in this system, further sampling for coral clonal structure and surveying for abundance of triggerfish and mussels will be required across the range of the coral, triggerfish, and mussels in the ETP and should be augmented with deployment of settlement plates. This knowledge of how coral populations persist in marginal habitats will provide insights for conservation of the existing diversity and preserving resilience on coral reefs.

\section{ACKNOWLEDGMENTS}

We thank the government of Costa Rica for facilitating research permits through 
SINAC and ACMIC. We appreciate the logistical support to facilitate fieldwork provided by CIMAR. This research was supported by NSF grant OCE- 0550294 to IBB and grants from the Vicerrectoría de Investigación (UCR) and CONARE to JC.

\section{RESUMEN}

Los ambientes marinos del Parque Nacional Isla del Coco experimentan perturbaciones extremas periódicamente como por ejemplo El Niño-Oscilación del Sur (ENOS) que han devastado las comunidades coralinas. La cobertura coralino se redujo drásticamente durante El Niño de 1982-83. Los corales escleractinios construyen la estructura física de los arrecifes así que la recuperación de estos ecosistemas depende de que los corales se recuperen. Los corales pueden reproducirse sexual y asexualmente, y el éxito relativo de cada forma de reproducción va a guiar el proceso de recuperación con implicaciones potenciales a la diversidad de las comunidades asociadas. En la mayoría de los arrecifes alrededor de la Isla del Coco, el coral masivo, Porites lobata, es la especie constructora predominante. Si la diversidad genotípica (clonal) de esta especie es alta, la diversidad de individuos va a ser más alta resultando en mayor resilencia frente a condiciones ambientales extremas. Alternativamente, una diversidad genotípica baja es indicativo de una estrategia reproductiva asexual posiblemente resultando en el mantenimiento de genotipos bien adaptados aunque la población decline. Aquí, usamos 11 marcadores microsatélite para investigar la contribución relativa de la reproducción sexual o asexual en la recuperación de los arrecifes en el Parque Nacional Isla del Coco. En la Isla del Coco se recolectaron muestras en: Punta Ulloa ( $n=17)$, Bahía Weston $(n=20)$ y Punta María $(n=20)$, y para comparar, se recolectaron muestras en localidades cerca de o en la costa continental de Costa Rica; Reserva Biológica Isla del Caño: Caño1 $(n=8)$, Caño2 $(n=10)$ y Caño5 ( $\mathrm{n}=11)$, y Tres Hermanas, Parque Nacional Marino Ballena $(n=4)$, utilizando un diseño de muestreo espacialmente explícito. Las colonias de la Isla del Coco son generalmente pequeñas $\left(>60 \%\right.$ de las colonias $\left.<0.5 \mathrm{~m}^{2}\right)$ y se observó poca reproducción asexual. En la mayoría de los sitios la reproducción era mayormente sexual $\left(\mathrm{N}_{\mathrm{G}} / \mathrm{N}=\right.$ 0.90-0.94; $\mathrm{G}_{\mathrm{O}} / \mathrm{G}_{\mathrm{E}}=0.63-0.74 ; \mathrm{D}=0.99$ ) o totalmente sexual $\left(\mathrm{N}_{\mathrm{G}} / \mathrm{N}=1.0 ; \mathrm{G}_{\mathrm{O}} / \mathrm{G}_{\mathrm{E}}=1.0 ; \mathrm{D}=1.0\right)$, por lo que consiste de colonias con genotipos únicos. En contraste, los sitios costeros tenían un ámbito de predominantemente asexual y genotípicamente pobre $\left(\mathrm{N}_{\mathrm{G}} / \mathrm{N}=0.5 ; \mathrm{G}_{\mathrm{O}} / \mathrm{G}_{\mathrm{E}}=0.11 ; \mathrm{D}=0.5\right)$ a totalmente sexual $\left(\mathrm{N}_{\mathrm{G}} / \mathrm{N}=1.0 ; \mathrm{G}_{\mathrm{O}} / \mathrm{G}_{\mathrm{E}}=1.0 ; \mathrm{D}=1.0\right)$. No hubo diferencia en diversidad genética (número de alelos por locus, número de alelos privados) o distribución de tamaño por región. La alta diversidad genotípica del Parque Nacional Isla del Coco indica reproducción sexual frecuente y el potencial para la recuperación rápida de los arrecifes después de perturbaciones severas. En los sitios costeros, la fragmentación asexual de colonias grandes $\left(>2.5 \mathrm{~m}^{2}\right)$ y por lo tanto, potencialmente colonias bien adaptadas, puede aumentar las resistencia y resilencia de los sistemas.

\section{REFERENCES}

Arnaud-Haond, S. \& K. Belkhir. 2007. Genclone: a computer program to analyse genotypic data, test for clonality and describe spatial clonal organization. Mol. Ecol. Notes 7: 15-17.

Bakus, G.J. 1975. Marine zonation and ecology of Cocos Island, off Central America. Atoll Res. Bull. 179: $1-11$.

Baums, I.B., M.W. Miller \& M.E. Hellberg. 2006. Geographic variation in clonal structure in a reef building Caribbean coral, Acropora palmata. Ecol. Monogr. 76: 503-519.

Baums, I.B. 2008. A restoration genetics guide for coral reef conservation. Mol. Ecol. 17: 2796-2811.

Baums, I.B., J.N. Boulay, N.R. Polato \& M. Hellberg. 2012. No gene flow across the Eastern Pacific Barrier in the reef-building coral Porites lobata. Mol. Ecol. doi: 10.1111/j.1365-294X.2012.05733.x.

Berry, F.H. \& W.J. Baldwin. 1966. Triggerfishes (Balistidae) of the eastern Pacific. Proc. Calif. Acad. Sci. 34: 429-474.

Boulay, J.N., J. Cortés, M. Hellberg \& I.B. Baums. in prep. Deciphering cryptic coral species reveals functional differences in ecology.

Brownstein, M.J., J.D. Carpten \& J.R. Smith. 1996. Modulation of non-templated nucleotide addition by tag DNA polymerase: Primer modifications that facilitate genotyping. Biotechniques 20: 1004-1010.

Coffroth, M.A. \& H.R. Lasker. 1998. Population structure of a clonal gorgonian coral: The interplay between clonal reproduction and disturbance. Evolution 52: 379-393.

Combosch, D.J. \& S.V. Vollmer. 2011. Population genetics of an ecosystem-defining reef coral Pocillopora damicornis in the Tropical Eastern Pacific. PLoS One 6: e2120010.2121371/journal.pone.0021200.

Cortés, J. 1992. The coral reefs of Golfo Dulce, Costa Rica - Ecological aspects. Rev. Biol. Trop. 40: 19-26.

Cortés, J. 1997. Biology and geology of eastern Pacific coral reefs. Coral Reefs 16 (Suppl.): S39-S46.

Cortés, J. 2008. History of marine research at Cocos Island, Costa Rica. Rev. Biol. Trop. 56 (Suppl. 2): 1-18.

Cortés, J. \& H. Guzman. 1998. Organisms of Costa Rican coral reefs: description, geographic distribution and natural history of Pacific zooxantellate corals (Anthozoa : Scleractinia). Rev. Biol. Trop. 46: 55-92. 
Cortés, J., C.E. Jiménez, A.C. Fonseca \& J.J. Alvarado. 2010. Status and conservation of coral reefs in Costa Rica. Rev. Biol. Trop. 58 (Suppl. 1): 33-50.

Dana, T.F. 1975. Development of contemporary eastern Pacific coral reefs. Mar. Biol. 33: 355-374.

Darwin, C. 1880. The Origin of Species by Means of Natural Selection or the Preservation of Favored Races in the Struggle for Life. John Murray, London.

Ekman, S. 1953. Zoogeography of the Sea. Sidgwick and Jackson Ltd., London.

Flot, J.F., A. Couloux \& S. Tillier. 2010. Haplowebs as a graphical tool for delimiting species: a revival of Doyle's "field for recombination" approach and its application to the coral genus Pocillopora in Clipperton. BMC Evol. Biol. 10: 372 310.1186/1471-2148-1110-1372.

Foster, N.L., I.B. Baums \& P.J. Mumby. 2007. Sexual verses asexual reproduction in an ecosystem engineer: the massive coral Montastraea annularis. J. Anim. Ecol. 76: 384-391.

Foster, N., I. Baums, J. Sanchez, C. Paris, I. Chollett, C. Agudelo, M. Vermeij \& P. Mumby. in review. Hurricane-driven patterns of clonality in an ecosystem engineer: the Caribbean coral Montastraea annularis. PLoS One

Glynn, P.W. \& J.S. Ault. 2000. A biogeographic analysis and review of the far eastern Pacific coral reef region. Coral Reefs 19: 1-23.

Glynn, P.W., S.B. Colley, C.M. Eakin, D.B. Smith, J. Cortés, N.J. Gassman, H.M. Guzman, J.B. Delrosario \& J.S. Feingold. 1994. Reef coral reproduction in the Eastern Pacific - Costa-Rica, Panama, and Galapagos-Islands (Ecuador). 2. Poritidae. Mar. Biol. 118: 191-208.

Grigg, R.W. \& R. Hey. 1992. Paleoceanography of the Tropical Eastern Pacific-Ocean. Science 255: 172-178.

Guzman, H.M. 1988. Distribución y abundancia de organismos coralívoros en los arrecifes coralinos de la Isla del Caño, Costa Rica. Rev. Biol. Trop. 36: 191-207.

Guzman, H.M. \& J. Cortés. 1989. Coral reef community structure at Caño Island, Pacific Costa Rica. P.S.Z.N.I: Mar. Ecol. 10: 23-41.

Guzman, H.M. \& J. Cortés. 1992. Cocos Island (Pacific of Costa-Rica) coral reefs after the 1982-83 El-Niño disturbance. Rev. Biol. Trop. 40: 309-324.

Guzman, H.M. \& J. Cortés. 2007. Reef recovery 20 years after the 1982-1983 El Niño massive mortality. Mar. Biol. 151: 401-411.

Hoegh-Guldberg, O., P.J. Mumby, A.J. Hooten, R.S. Steneck, P. Greenfield, E. Gomez, C.D. Harvell, P.F. Sale, A.J. Edwards, K. Caldeira, N. Knowlton, C.M. Eakin, R. Iglesias-Prieto, N. Muthiga, R.H. Bradbury, A. Dubi \& M.E. Hatziolos. 2007. Coral reefs under rapid climate change and ocean acidification. Science 318: $1737-1742$
Hughes, T.P., A.H. Baird, D.R. Bellwood, M. Card, S.R. Connolly, C. Folke, R. Grosberg, O. Hoegh-Guldberg, J.B.C. Jackson \& J. Kleypas. 2003. Climate change, human impacts, and the resilience of coral reefs. Science 301: 929 - 933.

Hunter, C.L. 1993. Genotypic variation and clonal structure in coral populations with different disturbance histories. Evolution 47: 1213-1228.

Legoff, M.C., O.G. Pybus \& A.D. Rogers. 2004. Genetic structure of the deep sea coral Lophelia pertusa in the northeast Atlantic revealed by microsatellites and internal transcibed spaces sequences. Mol. Ecol. 13: 537-549.

Lively, C.M., C. Craddock \& R.C. Vrijenhoek. 1990. Red queen hypothesis supported by parasitism in sexual and clonal fish. Nature 344: 864-866.

Maina, J., T.R. McClanahan, V. Venus, M. Ateweberhan \& J. Madin. 2011. Global gradients of coral exposure to environmental stresses and implications for local management. PLoS ONE 6(8): e23064. doi:10.1371/ journal.pone.0023064

Meirmans, P.G. \& P.H. Van Tienderen. 2004. GENOTYPE and GENODIVE: two programs for the analysis of genetic diversity of asexual organisms. Mol. Ecol. Notes 4: 792-794

Miller, K.J. \& D.J. Ayre. 2004. The role of sexual and asexual reproduction in structuring high latitude populations of the reef coral Pocillopora damicornis. Heredity 92: 557-568.

Miller, M.W., I.B. Baums \& D.E. Williams. 2007. Visual discernment of sexual recruits is not feasible for Acropora palmata. Mar. Ecol. Prog. Ser. 335: 227-231.

Peakall, R. \& P.E. Smouse. 2006. GENALEX 6: genetic analysis in Excel. Population genetic software for teaching and research. Mol. Ecol. Notes 6: 288-295.

Pinzón, J.H. \& T.C. Lajeunesse. 2011. Species delimitation of common reef corals in the genus Pocillopora using nucleotide sequence phylogenies, population genetics and symbiosis ecology. Mol. Ecol. 20: 311-325.

Pinzón, J.H., H. Reyes-Bonilla, I.B. Baums \& T.C. Lajeunesse. 2012. Contrasting clonal structure among Pocillopora (Scleractinia) communities at two environmentally distinct sites in the Gulf of California. Coral Reefs 3: 765-777.

Polato, N.R., G.T. Concepcion, R.J. Toonen \& I.B. Baums. 2010. Isolation by distance across the Hawaiian Archipelago in the reef-building coral Porites lobata. Mol. Ecol. 19: 4661-4677.

Polidoro, B.A., T. Brooks, K.E. Carpenter, G.J. Edgar, S. Henderson, J. Sanciangco \& D.R. Robertson. 2012. Patterns of extinction risk and threat for marine vertebrates and habitat-forming species in the Tropical Eastern Pacific. Mar. Ecol. Prog. Ser. 448: 93-104. 
Reusch, T.B.H., A. Ehlers, A. Hammerli \& B. Worm. 2005. Ecosystem recovery after climatic extremes enhanced by genotypic diversity. Proc. Natl. Acad. Sci. U.S.A. 102: $2826-2831$

Stoddart, J.A. 1984a. Genetical structure within populations of the coral Pocillopora damicornis. Mar. Biol. 81: 19-30.

Stoddart, J.A. 1984b. Genetic differentiation amongst populations of the coral Pocillopora damicornis off southwestern Australia. Coral Reefs 3: 149-156.
Stoddart, J.A. \& J.F. Taylor. 1988. Genotypic diversity: estimation and prediction in samples. Genetics 118: 705-711.

Veron, J. 2000. Corals of the World. Australian Institue of Marine Science, Townsville.

Wells, S.M. 1988. Coral Reefs of the World. Volume 1: Atlantic and Eastern Pacific. United Nations Environment Programme / International Union for Conservation of Nature and Natural Resources, Gland, Switzerland. 
APPENDIX TABLE 1

Microsatellite loci for Porites lobata. The primer sequences are preceded by the name of fluorescent dye used (6FAM, VIC, NED or PET; Applied Biosystems, CA). The type of repeat and the size of the polymerase chain reaction (PCR) product is given (in basepairs, bp). Loci were amplified in four multiplex and one singleplex reaction (Plex)

\begin{tabular}{|c|c|c|c|c|c|c|}
\hline Reference & $\begin{array}{l}\text { Marker } \\
\text { Name }\end{array}$ & Primer Sequence & Repeat & Size (bp) & $\begin{array}{l}\text { Annealing } \\
\text { Temp }\left({ }^{\circ} \mathrm{C}\right)\end{array}$ & Plex \\
\hline Polato et al. 2010 & PL0340 & $\begin{array}{l}\text { F: 6FAM-GTTTGCCTCTCTTCTGTTCATT } \\
\text { R: AACATTATGGCTAGTTCTTTGAACG }\end{array}$ & $\begin{array}{l}(\mathrm{ATCC}) 6 \mathrm{ATT}(\mathrm{CGTT}) \\
4 \text { TGTT }(\mathrm{CATT}) 3\end{array}$ & $216-275$ & 52 & A \\
\hline Polato et al. 2010 & PL0780 & $\begin{array}{l}\text { F: VIC-GCCAGTAGGTGGATACACTGTT } \\
\text { R: CAAGTACGTTGACGTCGTTG }\end{array}$ & $(\mathrm{ATT}) 4(\mathrm{GTT}) 7$ & $136-163$ & 52 & A \\
\hline Baums et al. 2012 & PL0905 & $\begin{array}{l}\text { F: NED-GGTCCAAAGTCCACCATCA } \\
\text { R: TGGTGGAAATAAGTGGTCGA }\end{array}$ & (ATC)9 ACC (ATC)9 & $126-183$ & 52 & A \\
\hline Polato et al. 2010 & PL1357 & $\begin{array}{l}\text { F:PET- ATGTCCCTGAAACGGAAGTA } \\
\text { R: GATGATGATGTTGTTGATGGTG }\end{array}$ & $\begin{array}{c}(\mathrm{ACC}) 7 \ldots(\mathrm{ATC}) 4 \\
\quad \ldots(\mathrm{ACC}) 7\end{array}$ & $252-300$ & 52 & $\mathrm{D}$ \\
\hline Baums et al. 2012 & PL1370 & $\begin{array}{l}\text { F: PET-GCACTGTCTGTAACAAGCGAA } \\
\text { R: CATATTGGAAGGAGGGCTC }\end{array}$ & $(\mathrm{GTT}) 8$ & $189-246$ & 54 & $\mathrm{E}$ \\
\hline Baums et al. 2012 & PL1483 & $\begin{array}{l}\text { F: 6FAM-AAACGTTCCCTATCCCATCC } \\
\text { R: GCAAAGCTGCTACATTTCACTAA }\end{array}$ & $(\mathrm{GTT}) 10$ & $143-173$ & 54 & $\mathrm{E}$ \\
\hline Polato et al. 2010 & PL1551 & $\begin{array}{l}\text { F: PET-TGTTTCTGAGTGGCTGTGCT } \\
\text { R: GGTTGGAAAGGGTCCTTCAT }\end{array}$ & (GTT) 8 & $178-196$ & 52 & A \\
\hline Polato et al. 2010 & PL1556 & $\begin{array}{l}\text { F: PET-CGTTGACGTAACCTTCACCA } \\
\text { R: CACAGGGTAACCTTCCTTGC }\end{array}$ & (ATC) 10 & $153-168$ & 56 & $\mathrm{~B}$ \\
\hline Polato et al. 2010 & PL1629 & $\begin{array}{l}\text { F: 6FAM-CCTTGGTTAATTTGCCCTTG } \\
\text { R: ACCAGTCCGGAGTCAAGCTA }\end{array}$ & $(\mathrm{GCT}) 8$ & $168-180$ & 52 & $\mathrm{D}$ \\
\hline Baums et al. 2012 & PL1868 & $\begin{array}{l}\text { F: VIC-TAAGCCACAGCAGGTGTACG } \\
\text { R: AAACGTTCCCTATCCCATCC }\end{array}$ & $(\mathrm{AAC}) 10$ & 179-206 & 52 & $\mathrm{D}$ \\
\hline Polato et al. 2010 & PL2069 & $\begin{array}{l}\text { F: PET-CGCAGTTCCTTTGATTTGGT } \\
\text { R: GTTTCTTTAGCGGTTGATGGCTTGTTAC }\end{array}$ & $(\mathrm{GTT}) 8$ & $249-267$ & 52 & $\mathrm{C}$ \\
\hline Polato et al. 2010 & PL2258 & $\begin{array}{l}\text { F: NED-ATTAGCGGATGAAGCGAAGA } \\
\text { R: TCCAATGTAACGCCAAATCA }\end{array}$ & (GAT) 10 & $217-250$ & 56 & B \\
\hline
\end{tabular}

